\title{
Supporting Social Activity as Part of the Sustainable Development Strategy
}

\author{
KatARZYNA CZAINSKA \\ Institute of Human Capital, Collegium of Business Administration, \\ SGH Warsaw School of Economics
}

\begin{abstract}
The article presents the results of the study the main purpose of which was to determine the level of social activity in Poland. However, the specific goal was to identify the possibilities of using employees' social activity in implementing the sustainable development strategy (SDS) in enterprises. As the presented study is part of a larger scientific project (statutory research) entitled Human capital management in the conditions of sustainable development, the conclusions of the analysis are the basis for further work, which will result in the development of a set of good practices for enterprises and other organisations in the field of human capital management in terms of using the potential and competences of employees active in the area of social work. The diagnosed tendency of the Polish population to work for the benefit of the social good allows the author to conclude that enterprises that want to implement the SDS should use the potential existing in socially engaged employees.
\end{abstract}

Keywords: sustainable development strategy, human capital management 


\section{Introduction}

Since 1983, the management function with regard to developing and supervising the implementation of the sustainable development strategy has been performed by the United Nations (UN). In its resolutions, the organisation sets strategic goals concerning major problems of the modern world. Such documents always emphasise the role of conscious citizens who, in cooperation with enterprises, should take care of the future of the global, national, and regional environment. In resolution 38/161 of 19 December 1983 and resolution 42/187 of 11 December 1987, sustainable development was defined as development implying meeting the needs of the present without compromising the ability of future generations to meet their own needs (UN, 1983; UN, 1987); importantly, such development refers not only to environmental and economic factors, but also to social factors. This thought was continued in another document - resolution 70/1 of 21 October 2015 (UN, 2015). Theoreticians and practitioners from various scientific disciplines and spheres of activity started working on the actual implementation of the idea of sustainable development. Many works on management science have also been published, in which authors discuss selected issues relating to the SDS in an organisation or, representing a holistic approach, try to formulate the objectives of the so-called sustainable organisation (Laszlo, 2008; Sudolska \& Lis, 2018).

The aim of this paper is to present the results of the study the main purpose of which was to determine the level of social activity in Poland. Moreover, the specific goal was to identify the possibilities of using employees' social activity in implementing the sustainable development strategy (SDS) in enterprises. Based on the analysis of the statistical data, it is demonstrated that Poles display considerable willingness to engage in voluntary work and thus there is no need to apply top-down practices popularising this form of activity. However, it is necessary for enterprises to create favourable conditions for providing support to employees and for integrating the organisation's strategy with employee preferences. The above assumption was formulated after the following was accomplished: 1/ defining the voluntary work market in Poland and identifying its actors; 2/ analysing publications concerning entrepreneurs' and managers' approaches to involvement in the SDS and voluntary work; 3 / identifying the potential of human resources in the area of voluntary work in Poland. The steps described above constitute the first stage of research concerning the issue of human capital management in enterprises aiming to pursue the SDS.

The study was conducted from June to August 2019 through in-depth desk research method and the statistical data analysis. 


\section{Voluntary work market actors in Poland}

Analogously to the general definition of a market, the voluntary work market can be defined as the area of an encounter between demand for and supply of work performed for the benefit of a given community, carried out voluntarily, for free and/or against remuneration, but without making any profit. Voluntary work market areas are defined officially (e.g. by nationwide institutions) or emerge at the grassroots level in response to an existing and noticed necessity (e.g. non-formalised individual or local initiatives). An example of the organised shaping of the voluntary work market on a global scale is the sustainable development strategy, for which the key to successful implementation has been, since the very emergence of this idea, the assumption that it requires active involvement of all market actors. 'All' is understood to comprise both individual entities (natural persons) and organisations, irrespective of their legal form and the geographical area in which they function.

A decision on starting or developing an enterprise's activity on the voluntary work market should be a strategic decision, and thus it must be preceded by an analysis of entities that are active on the market and could become partners in accomplishing the objectives defined by a given enterprise. Generally speaking, entities operating on the voluntary work market can be divided into: a) service providers (units/entities offering assistance in various forms), b) beneficiaries (units/entities provided with assistance), c) intermediaries (units/entities assisting in the process of service delivery from service providers to beneficiaries), d) controlling and monitoring entities (organisations established for the purposes of controlling, reporting and/ or overseeing the above-mentioned units/entities).

From the point of view of market partnership, an enterprise can cooperate with entities of various organisational and legal forms and of various scopes and areas of activity. The complexity of the voluntary work market has been depicted e.g. by creating a list of types of organisations in which non-profit (voluntary) work was carried out, namely:

a) foundations, associations, sports clubs, scout organisations, student organisations, the Voluntary Fire Service, Voluntary Mountain Rescue Service (GOPR), Voluntary Water Rescue Service (WOPR), the Polish Red Cross (PCK), citizens' committees;

b) facilities operated by associations, foundations or other non-governmental organisations, such as schools, kindergartens, cultural centres, internet newspapers, choirs, music bands, museums, theatres, clubs, care centres, clinics, health centres, occupational therapy workshops, etc.;

c) informal groups, including the more and more popular internet groups and/or clubs; 
d) churches, religious communities, and religious organisations;

e) schools, kindergartens, cultural centres, museums, choirs, etc., operated by parishes, religious orders or other religious organisations;

f) trade unions, workers' councils, personnel self-government bodies, employee savings and loan schemes, political parties, etc.;

g) offices, auxiliary units, government or local government institutions or their branches, or initiatives undertaken as part of the activity of such a branch (GUS, 2017).

The intersection of enterprises and all the entities listed above are people - employees who, apart from their professional work, engage in voluntary work in various organisations (formal - institutional volunteering) and/or initiatives (individual volunteering). Thus, the core of an enterprise's sustainable development strategy can be the estimation of the size of this intersection and the use of employee activities as the potential directions for shaping functional strategies in different areas of the SDS implementation.

\section{Approaches of enterprises to the voluntary work market}

Business theoreticians and practitioners have been aware of the necessity to respect the principles of sustainable development for many years. Even recognised creators of scientific management, e.g. Karol Adamiecki or Henry Ford, already noticed the social, economic, and environmental consequences of the failure to sustain the balance in economic activity (Czainska, 2010). The principle of systemic feedback between the behaviour of enterprises and their surroundings was aptly formulated by M.E. Porter and M.R. Kramer, who argued that businesses must reconnect company success with social progress (Porter \& Kramer, 2011). To justify their statement, the authors provided the following example of an environment-related feedback: if an enterprise, seeking to maximise its profits, does not take care of the environment, its costs will soon increase due to expenditure on treatment or obtaining production resources (e.g. water). At the same time, society will impose taxes and penalties on companies and introduce legal regulations providing protection against the destructive effects of enterprises' operations, and thus the spiral of costs and obstacles will be gathering pace. At the same time, M.E. Porter and M.R. Kramer emphasise that the concept of 'economic and social value' must not be based on the idea of redistributing company profits, but on a holistic strategy for expanding the total pool of economic and social value (Porter \& Kramer, 2011).

Unfortunately, the approaches of enterprises to pursuing the SDS objectives still vary. After R.W. Griffin, they can be divided into: 
a) obstructionist - where enterprises do as little as possible to solve social or environmental problems;

b) defensive - an enterprise does everything that is required of it legally, but nothing more than that;

c) accommodative - an enterprise meets its basic legal and ethical obligations, but will also go beyond their obligations in selected cases;

d) proactive - an enterprise views itself as a citizen in the society and proactively seeks for opportunities to contribute to the society (Griffin, 2004, pp. 122-126). In this article, only enterprises demonstrating the accommodative and proactive approaches are considered. A broad range of activities have been observed among such entities, which can be classified, after P. Wachowiak (Wachowiak, 2012, pp. 404-409), into the following groups: organisational, employee-related, social, business environment-related, and environmental (Table 1). Certainly, the concepts of corporate social responsibility and irresponsibility are narrower than the SDS (Kwiecień, 2018; Sokołowska-Durkalec \& Tabaszewska-Zajbert, 2018), however, the criteria indicated may also provide the basis for an analysis of the degree of SDS implementation in an enterprise.

Table 1. Criteria for evaluating CSR in an organisation

\begin{tabular}{|l|l|}
\hline \multicolumn{1}{|c|}{ Area } & \multicolumn{1}{|c|}{ Criteria } \\
\hline \multirow{5}{*}{ Organisational } & Economic, social, and environmental effects of the enterprise's activity \\
\cline { 2 - 3 } & Cooperation with key stakeholders \\
\cline { 2 - 3 } & Corporate social responsibility strategy \\
\cline { 2 - 3 } & Responsibility for implementing the corporate social responsibility strategy \\
\cline { 2 - 3 } & Reliability of information concerning corporate social responsibility \\
\hline \multirow{5}{*}{ Social } & Recruiting employees \\
\cline { 2 - 3 } & Remunerating employees \\
\cline { 2 - 2 } & Investing in employees \\
\cline { 2 - 2 } & Employment stability \\
\cline { 2 - 2 } & Work-life balance \\
\hline & Social involvement programme for the enterprise \\
\cline { 2 - 2 } & Pursuing activity for the benefit of the local community \\
\cline { 2 - 2 } & Employee volunteering \\
\cline { 2 - 2 } & Organising apprenticeships \\
\cline { 2 - 2 } & Cooperation with non-governmental organisations \\
\hline
\end{tabular}


cont. table 1

\begin{tabular}{|l|l|}
\hline \multicolumn{1}{|c|}{ Area } & \multicolumn{1}{c|}{ Criteria } \\
\hline $\begin{array}{l}\text { Business } \\
\text { environment- } \\
\text { related }\end{array}$ & Cooperation with customers \\
\cline { 2 - 3 } & Customer satisfaction \\
\cline { 2 - 3 } & Barrier-free accessibility (the issue of persons with disabilities) \\
\cline { 2 - 3 } & Cooperation with suppliers \\
\cline { 2 - 2 } & Anti-corruption measures \\
\hline \multirow{5}{*}{ Environmental } & Action plan aimed at reducing the enterprise's impact on the environment \\
\cline { 2 - 3 } & System for monitoring the enterprise's impact on the environment \\
\cline { 2 - 3 } & Implementing the Eco-Office principles \\
\cline { 2 - 3 } & Activities aimed at protecting the local environment \\
\cline { 2 - 3 } & Environmental training for employees \\
\hline
\end{tabular}

Source: Wachowiak, P. (2012: 404-409).

Table 2. Share of employee involvement in pro-social activities

\begin{tabular}{|l|c|c|c|c|c|}
\cline { 2 - 6 } \multicolumn{1}{c|}{} & \multicolumn{3}{c|}{ Employee involvement level } \\
\hline \multicolumn{1}{c|}{$\begin{array}{c}\text { Form of cooperation with the external } \\
\text { environment }\end{array}$} & none & low & medium & high & $\begin{array}{c}\text { very } \\
\text { high }\end{array}$ \\
\hline Patronage & $\mathrm{x}$ & $\mathrm{x}$ & & & \\
\hline Sponsoring & $\mathrm{x}$ & $\mathrm{x}$ & & & \\
\hline Cash donations & $\mathrm{x}$ & $\mathrm{x}$ & $\mathrm{x}$ & $\mathrm{x}$ & \\
\hline Donations in kind & & $\mathrm{x}$ & $\mathrm{x}$ & $\mathrm{x}$ & $\mathrm{x}$ \\
\hline Employee volunteering & & $\mathrm{x}$ & $\mathrm{x}$ & $\mathrm{x}$ & $\mathrm{x}$ \\
\hline Waste segregation in the enterprise (Eco-Office) & $\mathrm{x}$ & $\mathrm{x}$ & $\mathrm{x}$ & $\mathrm{x}$ \\
\hline $\begin{array}{l}\text { Promoting eco-friendly transport (e.g. going } \\
\text { to work by bike) }\end{array}$ & & $\mathrm{x}$ & $\mathrm{x}$ \\
\hline
\end{tabular}

Source: own study.

So far, the issue of enterprises' involvement in the idea of sustainable development has been considered mainly from the point of view of an enterprise that has adapted to the needs of its environment, without involving its employees in the related activities or by imposing the directions and forms of pro-social activity on employees (Table 2). Thus, top-down strategies and/or activities have been followed. Certainly, the success of such activities depends on many measurable and non-measurable, as well as predictable and unpredictable factors, and thus it is impossible to indicate which specific factors are of key importance. However, using knowledge derived from motivation theories, according to which actions taken as a result of employees' internal motivation are performed with greater involvement than actions that are 
imposed, i.e. externally motivated (Juchnowicz, 2012), it can be assumed that bottom-up strategies initiated by employees and/or adjusted to their out-of-work activity will also be pursued with considerable involvement and approval.

Thus, it seems right for managers of enterprises willing to pursue the SDS to adopt a matrix approach, consisting in adjusting selected directions of the enterprise's activity under the SDS to the pro-social activity of its employees. The first step that an enterprise should take is to estimate the potential of its present and future employees in voluntary work areas.

\section{The potential of human resources (HR) in voluntary work areas in the context of the sustainable development strategy: preliminary theoretical assumptions}

The HR potential can be considered at many levels. This article focuses on the number of people, the object of involvement and their competences. In the context of numbers, the HR potential should be understood as the number of employees (present and prospective) who represent a given feature and/or set of features. In the case of voluntary work, it is necessary to determine how many employees are involved in pro-social activities. Additionally, in accordance with the enterprise's recruitment strategy, it is necessary to estimate the percentage of persons, within the market of potential candidates, involved in voluntary work; these data can be used to evaluate the probability of the effective recruitment of persons who, when employed, will provide the foundations for the organisation's pro-social activities. The HR potential in the context of the object of involvement comprises: a) the form in which employees and candidates operate (individually or in cooperation with specific organisations); b) the areas in which they are involved in pro-social activity (e.g. animal protection, ecology, human rights protection, etc.); c) the types of work that they perform (e.g. advisory work, physical work, etc.). With T. Rostkowski's definition (Juchnowicz, 2014, p. 42) as the starting point, the competences-related potential comprises the knowledge, skills, predispositions, and attitudes of employees and candidates that can be used to implement the organisation's strategy aimed at adaptation to the SDS. As all the definitions provided above include the word 'potential', it should be borne in mind that the purpose of such a survey is to determine not only the current state, but, more importantly, also the scope (space) for development. 


\section{The potential of human resources in voluntary work areas in the context of the sustainable development strategy in Poland}

The broad understanding of the concept of sustainable development strategy is reflected e.g. in the set of statistical indicators devised by the European Union to measure the achievement of its particular goals. Such analyses are also performed at the national and regional level in individual Member States. In Poland, the key institution measuring sustainable development indicators is Statistics Poland (GUS). In accordance with the model used by EUROSTAT, Statistics Poland has developed a diagram for the construction and grouping of national indicators (Table 3).

Table 3. Diagram for the construction and grouping of Statistics Poland's national sustainable development indicators, in force until 2020

\begin{tabular}{|c|c|c|c|}
\hline Principles of & Integrated order & Thematic areas & $\begin{array}{c}\text { Number of } \\
\text { sustainable } \\
\text { development } \\
\text { indicators }\end{array}$ \\
\hline $\begin{array}{l}\text { social } \\
\text { development }\end{array}$ & social & $\begin{array}{l}\text { 1.1. Demographic changes } \\
\text { 1.2. Public health } \\
\text { 1.3. Social integration } \\
\text { 1.4. Education } \\
\text { 1.5. Access to the labour market } \\
\text { 1.6. Public safety } \\
\text { 1.7. Sustainable consumption patterns }\end{array}$ & $\begin{array}{l}4 \\
5 \\
4 \\
3 \\
5 \\
2 \\
3\end{array}$ \\
\hline \multicolumn{3}{|r|}{ total } & 26 \\
\hline $\begin{array}{l}\text { economic } \\
\text { development }\end{array}$ & economic & $\begin{array}{l}\text { 2.1. Economic development } \\
\text { 2.2. Employment } \\
\text { 2.3. Innovativeness } \\
\text { 2.4. Transport } \\
\text { 2.5. Sustainable production patterns }\end{array}$ & $\begin{array}{l}8 \\
3 \\
4 \\
1 \\
3\end{array}$ \\
\hline \multicolumn{3}{|r|}{ total } & 19 \\
\hline $\begin{array}{l}\text { environmental } \\
\text { development }\end{array}$ & environmental & $\begin{array}{l}\text { 3.1. Climate change } \\
\text { 3.2. Energy } \\
\text { 3.3. Air protection } \\
\text { 3.4. Marine ecosystems } \\
\text { 3.5. Fresh water resources } \\
\text { 3.6. Land use } \\
\text { 3.7. Biodiversity } \\
\text { 3.8. Waste management }\end{array}$ & $\begin{array}{l}3 \\
4 \\
4 \\
1 \\
3 \\
3 \\
2 \\
4\end{array}$ \\
\hline \multicolumn{3}{|r|}{ total } & 24 \\
\hline
\end{tabular}




\begin{tabular}{|c|c|c|c|}
\hline Principles of & Integrated order & Thematic areas & $\begin{array}{l}\text { Number of } \\
\text { sustainable } \\
\text { development } \\
\text { indicators }\end{array}$ \\
\hline $\begin{array}{l}\text { institutional } \\
\text { and political } \\
\text { development }\end{array}$ & $\begin{array}{l}\text { institutional } \\
\text { and political }\end{array}$ & $\begin{array}{l}\text { 4.1. Global partnership } \\
\text { 4.2. Policy of coherence and effectiveness } \\
\text { 4.3. Openness and participation } \\
\text { 4.4. Active citizenship }\end{array}$ & $\begin{array}{l}1 \\
2 \\
3 \\
1\end{array}$ \\
\hline \multicolumn{3}{|r|}{ total } & 7 \\
\hline \multicolumn{3}{|r|}{ Total indicators } & 76 \\
\hline
\end{tabular}

Source: based on: GUS (2011). Wskaźniki zrównoważonego rozwoju w Polsce. GUS. Urząd Statystyczny w Katowicach. Retrieved from: https://stat.gov.pl/cps/rde/xbcr/gus/oz_wskaznikizrownowazonego_rozwoju_Polski_us_kat.pdf (9.7.2019).

From the point of view of this article, area 4.4 (Institutional and political development/Active citizenship) is particularly interesting; under this area, a context indicator titled "overall indicator of involvement in voluntary work" was used. According to the definition adopted by Statistics Poland, this indicator should be interpreted as "the share of persons who devoted their voluntary and unpaid work and time to their local community or to people in need, as well as to activity in non-governmental organisations, in the total representative random sample of adult citizens" (GUS, 2011, p. 175). In other words, the indicator made it possible to estimate what percentage of Poles showed an interest in issues going beyond their private lives, trying e.g. to influence the functioning of their local communities or the activity of specific environmental or professional groups, to contribute to the elimination of social problems, and to help people in need (GUS, 2011, p. 175). For many years, involvement in voluntary work has been declared by more than one third of adult Poles (Table 4).

Table 4. Overall indicator of involvement in voluntary work in the years 2004-2009

\begin{tabular}{|c|c|c|c|c|c|}
\hline 2004 & 2005 & 2006 & 2007 & 2008 & 2009 \\
\hline $37 \%$ & $36 \%$ & $36 \%$ & $31 \%$ & - & $36 \%$ \\
\hline
\end{tabular}

Source: based on: GUS (2011). Wskaźniki zrównoważonego rozwoju w Polsce. GUS. Urząd Statystyczny w Katowicach. Retrieved from: https://stat.gov.pl/cps/rde/xbcr/gus/oz_wskaznikizrownowazonego_rozwoju_ Polski_us_kat.pdf (9.7.2019).

Based on the social and occupational analysis of the respondent group, it was found that the occupational groups that become involved in voluntary work most frequently include management personnel, specialists with higher education, and farmers. Moreover, it was observed that social activity increases proportionally to the 
education level. Among the not economically active, it was pupils and students who devoted the most of their time to voluntary work (GUS, 2011, pp. 175-176).

On 21 October 2015, UN General Assembly Resolution 70/1 was announced, titled: Transforming our world: the 2030 Agenda for Sustainable Development (UN, 2015). 17 new goals were set in that document. The change in priorities was accompanied by a change in the list of statistical indicators (Table 5).

Table 5. Statistics Poland's national sustainable development indicators for the years 2020-2030

\begin{tabular}{|l|c|}
\hline \multicolumn{1}{|c|}{ Goal } & Number of indicators \\
\hline 1. No poverty & 6 \\
\hline 2. Zero hunger & 13 \\
\hline 3. Good health and well-being & 19 \\
\hline 4. Quality education & 13 \\
\hline 5. Gender equality & 5 \\
\hline 6. Clean water and sanitation & 4 \\
\hline 7. Affordable and clean energy & 6 \\
\hline 8. Decent work and economic growth & 13 \\
\hline 9. Industry, innovation, infrastructure & 9 \\
\hline 10. Reduced inequalities & 4 \\
\hline 11. Sustainable cities and communities & 8 \\
\hline 12. Responsible consumption and production & 4 \\
\hline 13. Climate action & 4 \\
\hline 14. Life below water & 3 \\
\hline 15. Life on land & 6 \\
\hline 16. Peace, justice, and strong institutions & 7 \\
\hline 17. Partnerships for the goals & 3 \\
\hline Total indicators & 127 \\
\hline
\end{tabular}

Source: https://stat.gov.pl/obszary-tematyczne/gospodarka-spoleczna-wolontariat/wolontariat-i-praca-niezarob kowa-na-rzecz-innych/ (9.7.2019).

The number of indicators increased by $67 \%$, but unfortunately, the indicator of involvement in voluntary work was removed. However, becoming acquainted with the detailed indicator list may be important for enterprises that decide to join the efforts to implement the SDS. Just like in the previous years, the indicator list is closely correlated with the main goals of the strategy, and thus it constitutes a ready list of specific objectives that can be used by an enterprise to compile its own catalogue of objectives with respect to which it will undertake specific actions. 
At present, for the purposes of the statistical analysis of persons involved in voluntary work, this can be replaced by the set of indicators published by Statistics Poland in the area of 'Social economy, volunteering', group: 'Volunteering and unpaid work for the benefit of others'. This is even more justified due to the fact that Statistics Poland adopted a definition of pro-social work that equated it with volunteering, i.e. it decided that it was "activity undertaken voluntarily and with no remuneration, aimed at bringing benefits to persons or groups of persons from outside the household (excluding the volunteer's family)" (GUS, 2017, p. 9). Such an activity can be pursued for the benefit of society, the natural environment, a particular place or a community. Other important features of volunteering include devoting one's free time and pursuing an activity having the character of work, i.e. it could be pursued against payment (remuneration), but the person performing that work expects and receives no remuneration (GUS, 2017). Thus, Statistics Poland has adopted a broad definition of volunteering, as opposed to the Act of 24 April 2003 on Public Benefit Activity and Voluntary Work, according to which voluntary work is performed as part of the activity of an organisation/institution (Ustawa, 2003).

When analysing the Statistics Poland data for the year 2016, one can mainly observe that voluntary work was most often undertaken by persons aged 15 to 24 (44.9\%) and that the second most active group were persons aged 35 to 44 (40.7\%), having a stable work and family situation. Persons in gainful employment participated in individual voluntary work less frequently (33.1\%) than the unemployed (38.4\%). Among persons in gainful employment, the group that became involved in voluntary work most frequently were employers, and least frequently - the self-employed ( $34.5 \%$ vs. $30.9 \%$, respectively), with the average time devoted by particular economically active groups being at a similar level ( 6 hours). Over the 4 weeks preceding the survey, persons working part-time performed unpaid work more frequently than persons working full-time ( $35.8 \%$ vs. $32.9 \%$, respectively). Additionally, they devoted on average 2 hours more ( 8 hours) than full-time workers ( 6 hours) to such an activity. However, in both cases the dominant duration was 2 hours, with a median of 3 hours for full-time workers and 4 hours for part-time workers. The analysis of the involvement of students in individual voluntary work showed that the percentage was the highest for higher education students $(49.6 \%)$ and the lowest for persons attending vocational schools (34.7\%) (GUS, 2017).

In the case of voluntary work in organisations and institutions, the active group were working persons (9.6\%), especially those working part-time (15.1\%) (in comparison to $9.1 \%$ of full-time workers). In terms of occupational groups, they were mainly specialists (16.3\%), representatives of public authorities, senior officials and managers (13.6\%), and technicians and associate professionals (12.3\%). In terms of the main source of income, most volunteers were self-employed (11.3\%), while 
persons dependant on others (9.6\%) and persons whose main source of income was contract work (8.9\%) were less active. Pupils and students were also involved in voluntary work (11.9\%) (GUS, 2017).

Figure 1. Percentages of persons involved in individual voluntary work among inhabitants of Poland aged 15 and more, according to economic activity

(\%) in 2016

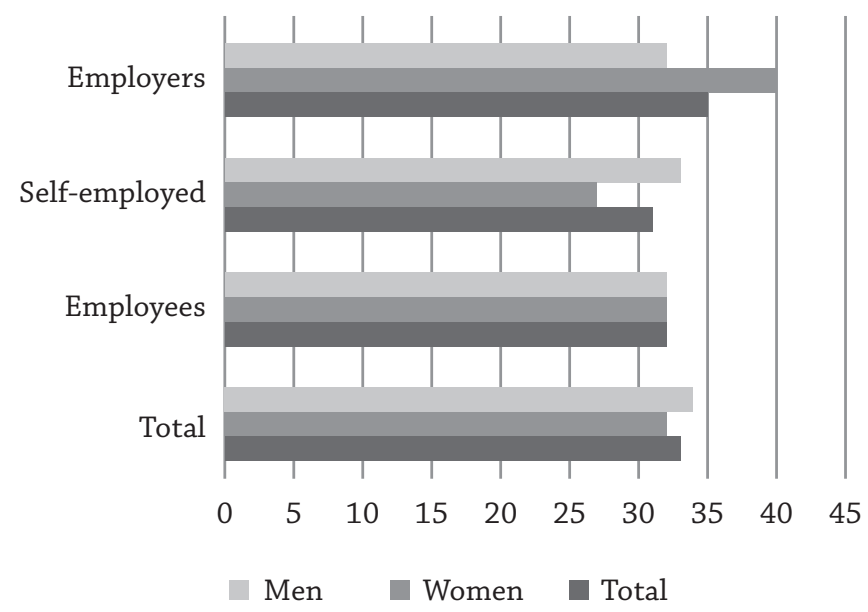

Source:Wolontariatw 2016 roku,Statistics Poland, Warszawa2017,p.40. Retrievedfrom:https://stat.gov.pl/obszarytematyczne /gospodarka-spoleczna-wolontariat/wolontariat-i-praca-niezarobkowa-na-rzecz-innych/ (9.7.2019).

It is difficult to find reliable, aggregate data concerning involvement in voluntary work at the European and global scale. The Eurostat database contains two such studies: 1/ a 2003 EU study, which analysed how Europeans spend their time, including time devoted to voluntary work (EC, 2003); 2/ A. Litwińska's study of 2006, in which the author presents the results of a survey concerning volunteering in selected EU countries (Litwińska, 2013). Unfortunately, these data are not suitable for comparison with the Statistics Poland data. The results of a survey ordered by the European Commission and carried out by GHK differ from the data published in national databases; according to the survey, Poland is among the states characterised by a low level of volunteering, estimated at 10-19\% (Table 6) (GHK, 2010, p. 7).

Considering the Statistics Poland data, one can notice the diverse nature of work carried out by volunteers, which implies a wide range of competences used and acquired by volunteers in the area of skills and experience (Table 7). 
Table 6. Level of volunteering in the European Union in 2010

\begin{tabular}{|l|l|l|}
\hline \multicolumn{1}{|c|}{ Level } & \multicolumn{1}{|c|}{ Level of volunteering } & \multicolumn{1}{c|}{ States } \\
\hline Very high & More than $40 \%$ & Austria, Netherlands, Sweden, UK \\
\hline High & $30 \%-39 \%$ & Denmark, Finland, Germany, Luxembourg \\
\hline Medium & $20 \%-29 \%$ & Estonia, France, Latvia \\
\hline Low & $10 \%-19 \%$ & $\begin{array}{l}\text { Belgium, Cyprus, Czech Republic, Ireland, Malta, Poland, } \\
\text { Slovakia, Romania, Slovenia, Spain }\end{array}$ \\
\hline Very low & Less than 10\% & Bulgaria, Greece, Italy, Lithuania \\
\hline
\end{tabular}

Source: based on: GHK (2010). Volunteering in the European Union. Final report. Retrieved from; https://ec.europa. eu/citizenship/pdf/doc1018_en.pdf (5.8.2019).

Table 7. Unpaid work categories analysed in the Statistics Poland study for 2016; large groups of occupations - according to the Classification of Occupations and Specialisations (KZiS 2010)

\begin{tabular}{|c|c|c|c|}
\hline \multicolumn{2}{|r|}{ Unpaid work types } & \multicolumn{2}{|r|}{$\begin{array}{l}\text { Large Classification of Occupations and } \\
\text { Specialisations groups }\end{array}$} \\
\hline Item & name & code & name \\
\hline \multirow[t]{3}{*}{1} & \multirow[t]{3}{*}{ Personal care and related workers } & 22 & Health professionals \\
\hline & & 32 & Health associate professionals \\
\hline & & 53 & Personal care and related workers \\
\hline \multirow[t]{2}{*}{2} & \multirow{2}{*}{$\begin{array}{l}\text { Business, administration, economy, } \\
\text { and management professionals }\end{array}$} & 24 & Economic and management specialists \\
\hline & & 33 & $\begin{array}{l}\text { Business and administration associate } \\
\text { professionals }\end{array}$ \\
\hline 3 & Domestic helpers, cleaners & 91 & Domestic helpers, cleaners \\
\hline \multirow[t]{3}{*}{4} & \multirow{3}{*}{$\begin{array}{l}\text { Personal and protective services } \\
\text { workers (including firefighters) }\end{array}$} & 51 & Personal services workers \\
\hline & & 54 & Protective services workers \\
\hline & & 94 & Associate professionals preparing meals \\
\hline \multirow[t]{6}{*}{5} & \multirow[t]{6}{*}{ Workers and craftsmen } & 71 & $\begin{array}{l}\text { Building and related trades workers } \\
\text { (excluding electricians) }\end{array}$ \\
\hline & & 72 & Metal, machinery and related trades workers \\
\hline & & 73 & Handicraft and printing workers \\
\hline & & 74 & Electrical and electronic trades workers \\
\hline & & 75 & $\begin{array}{l}\text { Food processing, woodworking, garment and } \\
\text { other craft and related trades workers }\end{array}$ \\
\hline & & 93 & $\begin{array}{l}\text { Associate labourers in mining, } \\
\text { manufacturing, construction and transport }\end{array}$ \\
\hline 6 & Elementary workers & 96 & $\begin{array}{l}\text { Refuse workers and other elementary } \\
\text { workers }\end{array}$ \\
\hline
\end{tabular}


cont. table 7

\begin{tabular}{|c|c|c|c|}
\hline \multicolumn{2}{|r|}{ Unpaid work types } & \multicolumn{2}{|r|}{$\begin{array}{l}\text { Large Classification of Occupations and } \\
\text { Specialisations groups }\end{array}$} \\
\hline Item & name & code & name \\
\hline \multirow[t]{2}{*}{7} & \multirow[t]{2}{*}{ Social and legal professionals } & 26 & Legal, social and cultural professionals \\
\hline & & 34 & $\begin{array}{l}\text { Legal, social, cultural and related associate } \\
\text { professionals }\end{array}$ \\
\hline \multirow[t]{3}{*}{8} & \multirow{3}{*}{$\begin{array}{l}\text { Agricultural, forestry and fishery } \\
\text { workers }\end{array}$} & 61 & Market-oriented agricultural workers \\
\hline & & 62 & Forestry and fishery workers \\
\hline & & 63 & Subsistence farmers and fishers \\
\hline \multirow[t]{4}{*}{9} & \multirow[t]{4}{*}{$\begin{array}{l}\text { Office personnel (secretaries, office } \\
\text { device operators) }\end{array}$} & 41 & $\begin{array}{l}\text { Secretaries, office device operators and } \\
\text { related professionals }\end{array}$ \\
\hline & & 42 & Customer services clerks \\
\hline & & 43 & $\begin{array}{l}\text { Financial and statistical and material } \\
\text { recording clerks }\end{array}$ \\
\hline & & 44 & Other clerical support workers \\
\hline \multirow[t]{3}{*}{10} & \multirow{3}{*}{$\begin{array}{l}\text { Vehicle assemblers, drivers and } \\
\text { operators }\end{array}$} & 81 & Mining and processing machinery operators \\
\hline & & 82 & Assemblers \\
\hline & & 83 & Vehicle drivers and operators \\
\hline 11 & Teaching and pedagogical specialists & 23 & Teaching and pedagogical specialists \\
\hline \multirow[t]{2}{*}{12} & \multirow[t]{2}{*}{ Sales and related workers } & 52 & Sales and related workers \\
\hline & & 95 & Street vendors and street service workers \\
\hline \multirow[t]{2}{*}{13} & \multirow{2}{*}{$\begin{array}{l}\text { Technicians, IT professionals, } \\
\text { information and communications } \\
\text { technology specialists }\end{array}$} & 25 & $\begin{array}{l}\text { Information and communications technology } \\
\text { specialists }\end{array}$ \\
\hline & & 35 & $\begin{array}{l}\text { Information and communications } \\
\text { technicians }\end{array}$ \\
\hline \multirow[t]{2}{*}{14} & \multirow[t]{2}{*}{$\begin{array}{l}\text { Physical, mathematical and } \\
\text { technical professionals }\end{array}$} & 21 & $\begin{array}{l}\text { Physical, mathematical and technical } \\
\text { specialists }\end{array}$ \\
\hline & & 31 & $\begin{array}{l}\text { Physical, chemical and technical associate } \\
\text { professionals }\end{array}$ \\
\hline
\end{tabular}

Source: GUS (2017). Wolontariat w 2016 roku. Warszawa: GUS, p. 77.

\section{Conclusion}

Apart from problems related to the current operations, enterprises have always had to deal with competition and the need to acquire customers. These challenges are now accompanied by new problems with recruiting and retaining valuable employees. Additionally, societies, both in global and local terms, expect that economic organisations will become involved in the sustainable development strategy. This 
situation seems overwhelming, especially if an enterprise functions with no holistic vision of its place on the market and acts only reactively. In the meantime, positive statistical data concerning the willingness of the Polish population to engage in prosocial work allow for the conclusion that enterprises that include in their personal strategy an analysis of the voluntary activity pursued by its present and prospective employees, and then combine such data with the SDS guidelines, will experience positive effects not only in the sphere of corporate image, as it was e.g. in the case of CSR (Zaleśna, 2018), but also in the sphere of human resources management. The ways in which this assumption is put into action will provide the author with the basis for further, in-depth studies.

\section{References}

Czainska, K. (2010). Odkryćzarządzanie. Warszawa: Wydawnictwo Profesjonalne PWN. GHK (2010). Volunteering in the European Union. Final report. GHK. Retrieved from: https://ec.europa.eu/citizenship/pdf/doc1018_en.pdf (5.8.2019).

GUS (2011). Wskaźniki zrównoważonego rozwoju w Polsce. GUS. Urząd Statystyczny w Katowicach. Retrieved from: https://stat.gov.pl/cps/rde/xbcr/gus/oz_wskazniki_ zrownowazonego_rozwoju_Polski_us_kat.pdf (9.7.2019).

GUS (2017). Wolontariat w 2016 roku. Warszawa: GUS.

Griffin, R.W. (2004). Podstawy zarządzania organizacjami. Warszawa: Wydawnictwo Naukowe PWN.

Juchnowicz, M. (2012). Zaangażowanie pracowników. Warszawa: PWE.

Juchnowicz, M. (Ed.) (2014). Zarządzanie kapitałem ludzkim. Procesy - narzędzia - aplikacje. Warszawa: Polskie Wydawnictwo Ekonomiczne.

EC (2003). Time use at different stages of life Results from 13 European countries July 2003. Luxembourg: Office for Official Publications of the European Communities.

Kwiecień, A. (2018). Znaczenie społecznej odpowiedzialności w działalności przedsiębiorstwa. In: K. Bratnicka - Myśliwiec, A. Dyląg, B.J. Gabryś (Eds). Proaktywność i podejmowanie ryzyka $w$ procesie rozwoju organizacji. Kraków: Wydawnictwo Uniwersytetu Jagiellońskiego.

Laszlo, Ch. (2008). Firma zrównoważonego rozwoju. Warszawa: Studio Emka.

Litwinska, A. (2013). Eurostat data on volunteering (potential and gaps). Retrieved from: https://www.eesc.europa.eu/en/news-media/presentations/eurostat-data-volunteering-potential-and-gaps (10.7.2019).

ONZ (1987). Rezolucja Zgromadzenia Narodowego Organizacji Narodów Zjednoczonych nr 42/187 z 11 grudnia 1987 roku. Retrieved from: https://www.un.org/documents/ga/res/42/ares42-187.htm (9.7.2019).

ONZ (2015). Rezolucja Zgromadzenia Narodowego Organizacji Narodów Zjednoczonych nr 70/1. Przekształcamy nasz świat: Agenda na rzecz zrównoważonego 
rozwoju 2030. Retrieved from: https://www.gov.pl/documents/910151/911704/ Agenda_2030_na_rzecz_zrownowazonego_rozwoju.pdf/d56cd332-4ba5-20359439-5a8a5212cbed (9.7.2019).

Porter, M.E., \& Kramer, M.R. (2011, May). Tworzenie wartości dla biznesu i społeczeństwa. Harvard Business Review Polska, 36-55.

Sokołowska-Durkalec, A., \& Tabaszewska-Zajbert, E. (2018). Społeczna nieodpowiedzialność przedsiębiorstwa - identyfikacja nurtów badawczych, założeń i uwarunkowań. Przedsiębiorczość i zarzq̨dzanie, XIX, 6, part II, 35-46.

Sudolska, A., \& Lis A. (2018). Sustainable Enterprise and Organization: Systematic Literature Review. Przedsiębiorczość i Zarządzanie, XIX, 6, part I, 119-131.

Ustawa z dnia 24 kwietnia 2003 r. o działalności pożytku publicznego i o wolontariacie (Dz.U.2019.0.688 t.j.).

Wachowiak, P. (2012). Pomiar społecznej odpowiedzialności przedsiębiorstwa - autorska propozycja. In: P. Wachowiak (Ed.). Człowiek w organizacji. Teoria i praktyka. Warszawa: Oficyna Wydawnicza Szkoły Głównej Handlowej w Warszawie.

Zaleśna, A. (2018). CSR i pozyskiwanie nowych pracowników - moderujący efekt zakładki „kariera” na stronie internetowej przedsiębiorstwa. In: I. Stańczyk, S. Twaróg (Eds.). Człowiek w organizacji. Kraków: Wydawnictwo Uniwersytetu Jagiellońskiego.

\section{Katarzyna Czainska}

Associate Professor (PhD, DSc) of economic sciences in the field of management. Currently, she works at the Institute of Human Capital at SGH Warsaw School of Economics. In the years 2007-2013 as a member of international research teams, she conducted research and open lectures at foreign universities related to the topic of strategic and multicultural management. Nowadays, she focuses on human capital management problems. She also has extensive professional experience in project management in the banking sector.

e-mail address: kczain@sgh.waw.pl

ORCID: 0000-0001-5863-8638 